Peter Lauritsen og

Stinne Højer Mathiasen

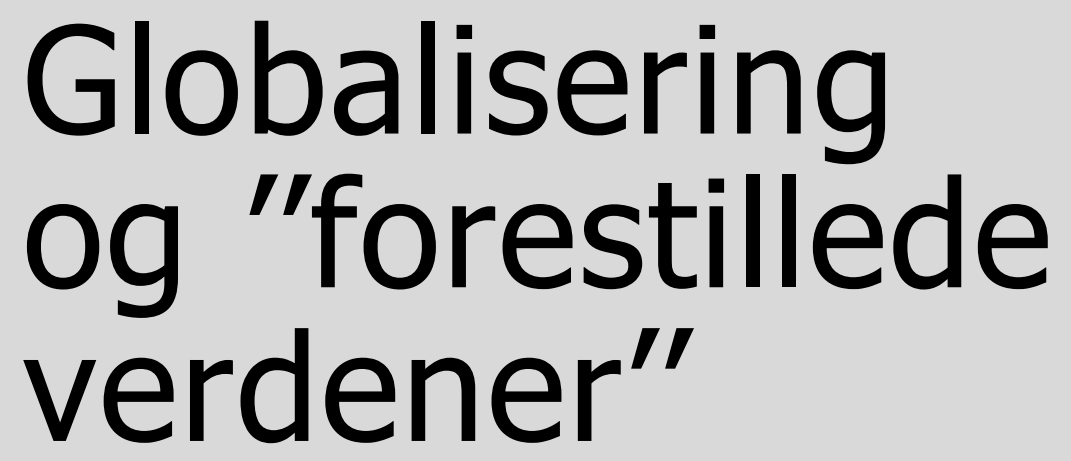

\title{
En kvalitativ undersøgelse baseret på børnetegninger fra to landsbyer i Peru
}

På baggrund af en analyse af tegninger lavet af børn fra to landsbyer i Peru kritiseres en globaliseringsforståelse, som beskriver, hvordan globale flow giver anledning til nye "forestillede verdener". Således afslører tegningerne forskelle mellem de to landsbyer, men disse kan ikke relateres til brug af fjernsyn, og dermed tilstedeværelsen af et globalt flow, i den ene landsby. Dermed peger undersøgelsen på behovet for yderligere undersøgelser af globalisering udført i specifikke lokaliteter ved hjælp af kvalitative metoder. 

dette slogan forsøger Samsung at placere sig som central globaliseringsaktør, og virksomheden udsteder tilsyneladende invitationer til alle.

Umiddelbart er der ikke noget usædvanligt ved Samsungs reklame. Tværtimod hører man ofte virksomheder, forskere og politikere love medlemskab af en velstående og veludviklet klub; et medlemskab som erhverves ved hjælp af IKT. Men Samsungs skilt hænger et sted i Lima, hvor befolkningen ikke hører til de fattigste, så selvom alle principielt er inviteret, er det ikke alle, der modtager invitationen. Dertil kommer, at omkring 10\% af den peruanske befolkning er analfabeter. Mange flere forstår ikke engelsk og er derfor ikke i stand til at læse invitationen. Og selv i den situation, hvor budskabet faktisk blev opfattet, kunne der stadig være problemer. Peru er et fattigt land, og mange har ikke mulighed for at købe IKT. Skulle køberen have råd, er det ikke sikkert, at der er elektriske installationer dér, hvor apparatet ønskes placeret. Og hvis apparatet skal tilsluttes telefonen, må det undersøges, om dette overhovedet er muligt.

Men hvad nu hvis problemerne overvindes, og et apparat erhverves og tilsluttes? Medfører det, at køberen globaliseres? Hvad betyder det at blive globaliseret? Og hvordan kan globalisering overhovedet gøres til genstand for empirisk undersøgelse?

\section{Introduktion}

Samsungs skilt er et eksempel på, hvordan globaliseringsdiskurser i mange tilfælde lever et selvstændigt liv uden klar forbindelse til de praksisser, som de hævder at repræsentere. Dette er måske særlig udbredt i kommercielle slogans, men man kan også iagttage denne "praksisuafhængighed" andre steder: I mediernes reportager, i politikernes taler og i akademiske analyser. Eksemplet viser også, hvordan nogle italesættelser udviser en fundamental tro på, at IKT er adgangsnøglen til det globale fællesskab; en overbevisning som har stor udbredelse, også i en dansk sammenhæng (Dybkjær \& Lindegaard 2000). Ofte er sådanne beskrivelser forankret i en dikotomisk forståelse af globalisering, hvor nogle mennesker siges at være koblet til globale kredsløb, mens andre er koblet fra. Eller der redegøres for, hvordan globalisering både er en "samlende" og en "splittende" proces, hvor en globaliseret elite lægger afstand til et lokaliseret proletariat (Bauman 1999; Castells 1996).

Ovenstående yder ikke fuld retfærdighed til de nuancer, som også findes i globaliseringslitteraturen. Men der er en tydelig tendens til at diskutere globalisering uden tilstrækkelig forbindelse til empiriske undersøgelser, og i de tilfælde hvor empiriske data faktisk inddrages, sker det ofte i analyser af globalisering på makro-niveau (Castells 1996; Tsing 2000). Derved udviskes globaliseringsbegrebets forbindelse til specifikke lokaliteter og de særlige forhold, som her gør sig gældende. 


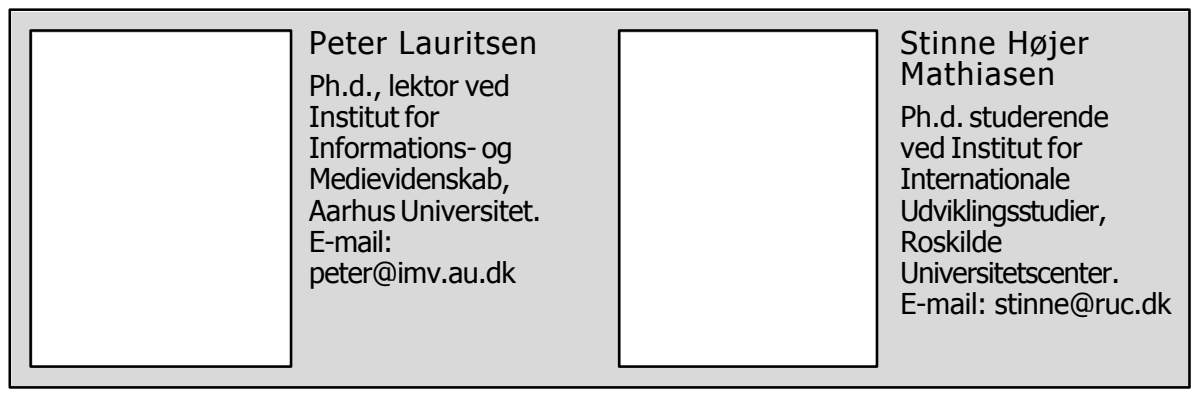

Denne artikel kan betragtes som et bidrag til en diskussion af måder, hvorpå globaliseringsdebatten kan suppleres med nye undersøgelser og perspektiver. Udgangspunktet er en kritik af globaliseringsforståelser, som vægter menneskers, artefakters og symbolers stadigt accelererende cirkulation på tværs af traditionelle grænser og skel. Kritikken knyttes især til Appadurais arbejde om globale flow, hvori det argumenteres, at sådanne flow, som bl.a. opstår i tilknytning til brug af IKT, leverer ressourcer til nye "forestillede verdener" (Appadurai 1996). Disse er ikke begrænset til specifikke lokaliteter, regioner eller nationalstater; tilkoblingen til de globale flow giver tværtimod mulighed for konstruktion af virtuelle, globale fællesskaber.

I tilknytning hertil beskriver artiklen en kvalitativ, empirisk undersøgelse af globalisering. Det drejer sig om en undersøgelse udført i Andesbjergene i Peru, hvor børn i to landsbyer blev bedt om at tegne deres "fællesskab", som de ønskede, det ville tage sig ud i fremtiden. Undersøgelsen kan betragtes som mikro-sociologisk, og den tager sigte på at afprøve Appadurais begreb om forestillede verdener ved brug af kvalitativ metode i en specifik kontekst. Som det vil blive beskrevet, illustrerer undersøgelsen nogle svagheder ved forestillingen om globale flow som byggesten for nye "verdener", ikke mindst i tilknytning til den effekt som Appadurai tillægger elektroniske medier. Således viser det sig, at tilstedeværelsen af globale flow, her specifikt formidlet af fjernsyn, ikke nødvendigvis fører til nye forestillede fællesskaber. Dermed peges på behovet for yderligere undersøgelser, som kan medvirke til at "situere" globaliseringsbegrebet.

\section{Globalisering}

Globalisering er et paraplybegreb, hvorunder mange forskellige diskussioner føres: nationalstatens afvikling, kapitalismens ekspansion, neo-liberal kolonialisering, identitetsdannelse, informationsteknologiens spredning, tredjeverdenslandes forarmelse eller fremgang, forholdet mellem det lokale og globale og så videre. Globalisering er med andre ord et uhåndterligt begreb uden fast betydning og indhold, og det kunne i forlængelse heraf være fristende helt at afvise begrebet (Hirst \& Thompson 2002). Men risikoen er, at man derved "melder sig ud" af en række væsentlige og aktuelle diskussioner. Derfor kan det være 
konstruktivt at følge Tsings (2000) analogi: Selvom man kritiserer globaliseringsbegrebet, forsvinder det ikke. Det er som med spøgelser. Det er muligt, at man ikke selv tror på deres eksistens, men der er alligevel tale om et interessant fænomen, fordi mange mennesker handler ud fra en overbevisning om, at spøgelser faktisk eksisterer. Ifølge Tsing må globaliseringsforskerens kritik altså funderes på et konstruktivt engagement, som tager begrebet (spøgelser eller globalisering) alvorligt; en kritik som forsøger at gendrive fænomenet risikerer at blive betragtet som irrelevant.

\section{Globale flow}

Samsungs reklame kan betragtes som en illustration til en fortælling, der jævnligt lanceres. Ifølge denne foregår der i disse år en hastig globalisering, som karakteriseres ved en komprimering af tid og sted. Denne tankegang kan føres tilbage til McLuhan (1964), der som følge af spredningen af elektroniske medier beskriver verden som "sammentrukket" og "imploderet"; karakteristika som leder McLuhan til metaforen om "den globale landsby."

I dag er "globalisering som komprimering" ligeledes central, og f.eks. siger Beck med reference til Giddens:

So does globalization conjure away distance. It means that people are thrown into transnational lifestyles that they often neither want nor understand - or following Anthony Giddens's definition, it means acting and living (together) over distances, across the apparently separate worlds of national states, religions, regions and continents (Beck 2000:20).

Denne komprimering af tid og sted relateres først og fremmest til den hastige udvikling og spredning af IKT. Med teknologien er det blevet muligt at "handle på distancen", og resultatet er, at "verden er skrumpet" (Ribeiro 1998).

I tilknytning til "komprimeringstesen" spiller idéen om globale flow ofte en vigtig rolle. Tanken er, at bl.a. brug af IKT medfører, at penge, ideologier, symboler og informationer flyder hurtigere og over større afstande, end det tidligere var tilfældet. Som nævnt har Appadurai $(1996,1999)$ argumenteret, at globalisering kan ses i lyset af en sådan flow-tankegang. Det teoretiske afsæt er Benedict Andersons analyse af nationalstatens opståen (Anderson 1999). Ifølge Anderson spiller "the convergence of capitalism and print technology" her en væsentlig rolle (Anderson 1999:46). Ved at læse om andre mennesker, steder og hændelser kunne befolkningen få en følelse af fællesskab med aktører, som de ikke umiddelbart var i nærhed af. Dette kalder Anderson for et forestillet fællesskab ("imagined community"). Appadurai overtager i vid udstrækning denne analyse, men sigtet er, i modsætning til Anderson, at vise hvordan nye fællesskaber medvirker til en afvikling af nationalstaten. Appadurai taler i den forbindelse om konstruktionen af "forestillede verde- 
ner" ("imagined worlds"), som baserer sig på de ressourcer, der leveres af globale flow.

Ifølge Appadurai må globaliseringsstudier forholde sig til "the relationship among five dimensions of global cultural flows..." (Appadurai 1996:33). Det drejer sig om "ethnoscape", der dækker over individers eller gruppers stigende mobilitet; "technoscape" som refererer til teknologiernes cirkulation; "financescape" som knytter sig til pengenes kredsløb; "mediascape" som har at gøre med mediernes spredning og det heraf stigende informationsflow, og endelig knytter "ideoscape" sig til flow med politisk og ideologisk indhold.

Om sammenhængen mellem disse "scapes" og konstruktionen af nye forestillede verdener siger Appadurai:

These landscapes are the building blocks of what (extending Benedict Anderson) I would like to call imagined worlds, that is, the multiple worlds that are constituted by the historically situated imaginations of persons and groups spread around the globe... An important fact of the world we live in today is that many persons on the globe live in such imagined worlds (and not just in imagined communities) and thus are able to contest and sometimes even subvert the imagined worlds of the official mind and the entrepreneurial mentality that surround them (Appadurai 1996: 33).

Med de globale flow følger ressourcer til konstruktion af nye forestillede verdener. Ifølge Appadurai medvirker ressourcerne til en "frisættelse af forestillingsevnen", og de konstruerede verdener er ikke længere bundet til lokalsamfundets eller nationalstatens grænser (Appadurai 1996:31).

I forhold til denne artikels empiriske undersøgelse er det især "mediascape", som er interessant. Det vil sige forståelsen af, at Internet, fjernsyn, radio etc. giver mulighed for, at folk kan forestille sig andre fællesskaber end dem, de traditionelt har været tilknyttet:

More persons in more parts of the world consider a wider set of possible lives than they ever did before. One important source of this change is the mass media, which present a rich ever-changing store of possible lives, some of which enter the lived imaginations of ordinary people more successfully than others (Appadurai 1996:53).

Som tidligere nævnt er denne antagelse om brug af IKT som forbindelseslinje til "det globale" gennemgående for mange beskrivelser af globalisering (Castells 1996; Waters 2001). Tilstedeværelsen af IKT kan sikre tilkoblingen til den globale verden, og omvendt forhindrer fraværet af disse teknologier en sådan tilkobling og efterlader områder og befolkningsgrupper isoleret og frakoblet globaliseringen. 
"Komprimering" og "flow" knytter sig til en globaliseringsforståelse, hvor mennesker, penge, teknologi og symboler er sat i bevægelse med stor hastighed, og konsekvenserne er tilsyneladende radikale: nationalstatens opløsning (Appadurai 1996; Beck 2000), øget social differentiering (Bauman 1999), stigende homogenisering og nye fundamentalistiske identitetsdannelser (Barber 1995). Men begreberne er ikke uden problemer, ikke mindst fordi analyserne ofte holdes på et generelt og overordnet niveau uden tilstrækkelig forankring i empiriske undersøgelser udført i specifikke lokaliteter.

I litteraturen ser man eksempelvis, at karakteristikken af globalisering som komprimering af tid og sted i mange tilfælde følges af en reference til David Harveys bog The Condition of Postmodernity (1990). Imidlertid omhandler denne bog ikke globalisering som sådan, og den fremsætter ikke empirisk belæg for "komprimerings-hypotesen". I en kritik af sociologisk og antropologisk globaliseringsforskning siger Tsing:

For me the space and time section [of Harvey's book] is the least satisfying of the book. Harvey describes categories for understanding human encounters with space and time, representations of space and time in the arts and letters (and, in one chapter, in two films), and anecdotes about space and time in the capitalist work-place. No ethnographic sources for understanding spatial and temporal texture or diversity are consulted... In this context, it is strange that anthropologists so often pick up only the "acceleration of time-space compression" and "flexible accumulation" out of this book... The result is that a selection of Harveys terms is used to build a noncultural and nonsituated futurist framework (Tsing 2000:341, kursivering tilføjet).

Med andre ord fremhæver Tsing, at selvom Harvey beskriver komprimering af tid og sted uden brug af etnografiske ressourcer, så importeres begrebet ukritisk i mange antropologiske arbejder. Implikationen er en forståelse, som ikke "situerer" globalisering i specifikke lokaliteter.

Et parallelt problem opstår i tilknytning til Appadurais, ligeledes ofte citerede, teori om flow. Som beskrevet omfortolker Appadurai begrebet om "imagined communities" til en globaliseret verden, hvor flere mennesker, teknologier og symboler er i stadigt hastigere bevægelse. Trods de hyppige referencer er der imidlertid en mangel på undersøgelser, som empirisk søger at afprøve denne hypotese og dens eventuelle implikationer. Konkret betyder det en underbelyst relation mellem de nye ressourcers tilstedeværelse og den faktiske konstruktion af en forestillet verden. I hvilket omfang og i hvilke situationer er det f.eks. en nødvendig følge af brug af IKT, at der gøres nye forestillinger? Hvilke andre betingelser må være opfyldt for, at nye forestillede verdener opstår? Og hvilke konkrete forandrede forestillinger kan man i givet fald finde i specifikke kontekster? 
Samlet set illustrerer den ovenstående skitse en væsentlig udfordring for globaliseringsforskningen, nemlig at udføre empiriske undersøgelser af globalisering i specifikke lokaliteter. Det følgende er i forlængelse heraf tænkt som en il-lustration, som udover at vise, hvordan Appadurais idé om nye forestillede verdener kan udfordres, også viser, hvordan globalisering kan udforskes lokalt ved hjælp af kvalitative metoder. Det drejer sig i dette tilfælde om en tegnemetode, som er blevet udviklet med inspiration fra Grounded Theory (Glaser \& Strauss 1967; Strauss \& Corbin 1990). Det viser sig primært i bestræbelserne på at læse forståelsen ud af det empiriske materiale samt anvende forskellige kodningsprocedurer i dette arbejde (Lauritsen \& Mathiasen 2003).

\section{Cunya og Ccarhuahurán}

Cunya og Ccarhuahurán er to små, afsidesliggende landsbyer i Andesbjergene i Peru. De er beliggende i et af landets fattigste områder og var ydermere hårdt ramt af borgerkrigen mellem guerillabevægelsen "Den lysende sti" og den peruanske hær i firserne og i starten af halvfemserne (Stern 1998). Selvom borgerkrigen sluttede for mere end ti år siden, er den stadig nærværende for store dele af befolkningen. Mange mistede familiemedlemmer eller nære venner, og mange skulle bygge deres tilværelse op fra grunden, da kampene blev indstillet.

Med borgerkrigens afslutning er en række forbindelser til omverdenen blevet styrket. Infrastrukturen er blevet udviklet, og der er nu en vej (ganske vist ofte vanskelig fremkommelig) til de to landsbyer. Det betyder, at varer nemmere kan transporteres til og fra det nærliggende marked, ligesom et stort antal hjælpeorganisationer er rykket ind i området med udvikling af bl.a. landbrugsproduktion samt politiske, juridiske og sociale institutioner til følge. På undersøgelsestidspunktet var det dog kun Cunya, som havde udviklingsorganisationernes opmærksomhed.

Yderligere er der nogle steder sket en væsentlig teknologisk udvikling. Der er f.eks. etableret radiokontakt mellem flere landsbyer, især med henblik på at kunne advare om eventuel guerilla-aktivitet. Der er ligeledes, hvilket er væsentligt for det følgende, kommet fjernsyn i nogle landsbyer. Dette er tilfældet i Cunya, hvorimod Ccarhuahurán ikke havde denne forbindelse til omverdenen.

I en globaliseringsterminologi kan man sige, at udviklingsaktiviteterne (især i Cunya) i vid udstrækning har bestået i at etablere forbindelse til flow på forskellige niveauer, hvor fjernsynet er det mest oplagte eksempel på et globalt flow. Derfor kunne man, ikke mindst på baggrund af Appadurais arbejde, forvente, at fjernsynsbrugen ville medfører konstruktionen af nye forestillede verdener, og i forlængelse heraf var det et væsentligt formål med undersøgelsen at indhente viden om disse fællesskaber. 


\section{Tegneworkshops}

I to tegneworkshops, som blev gennemført $\mathrm{i}$ henholdsvis Cunya og Ccarhuahurán, blev i alt 25 børn i alderen 8-13 år bedt om at tegne ting og aktiviteter, som de gerne ville have i deres landsby, når de blev voksne ${ }^{1}$. Børnene havde erfaring med at tegne, men der var ikke tale om en hverdagsaktivitet, først og fremmest på grund af de økonomiske udgifter forbundet med indkøb af materialer. At tegne var således en begivenhed, som børnene glædede sig til og engagerede sig i, hvilket var en væsentlig årsag til valget af metoden. Samtidig blev det fundet hensigtsmæssigt, at bruge tegningerne som et konkret udgangspunkt for interview.

Børnene tegnede i én til to timer, og de efterfølgende interview udfoldede sig omkring tre spørgsmål: (1) Hvad har du tegnet? (2) Hvorfor har du tegnet netop disse elementer? (3) Hvor har du hørt om eller set disse elementer? I Cunya blev der yderligere stillet spørgsmål til børnenes brug af fjernsynet.

I det følgende vil undersøgelsens resultater blive beskrevet $i$ to trin. I det første beskrives nogle iøjnefaldende forskelle mellem tegningerne fra de to landsbyer. Med inspiration fra Anderson/Appadurai kan man sige, at det vises, hvordan børnene beskriver to vidt forskellige forestillede fællesskaber (der dog også har en væsentlig lighed). I det andet gives et indtryk af fjernsynsbrugen i Cunya, og det undersøges, hvilken rolle dette "mediascape" spiller for etableringen af forestillede verdener i Cunya.

\section{Analyse af tegningerne}

For at give et indtryk af tegningerne kan det være nyttigt at præsentere nogle eksempler.

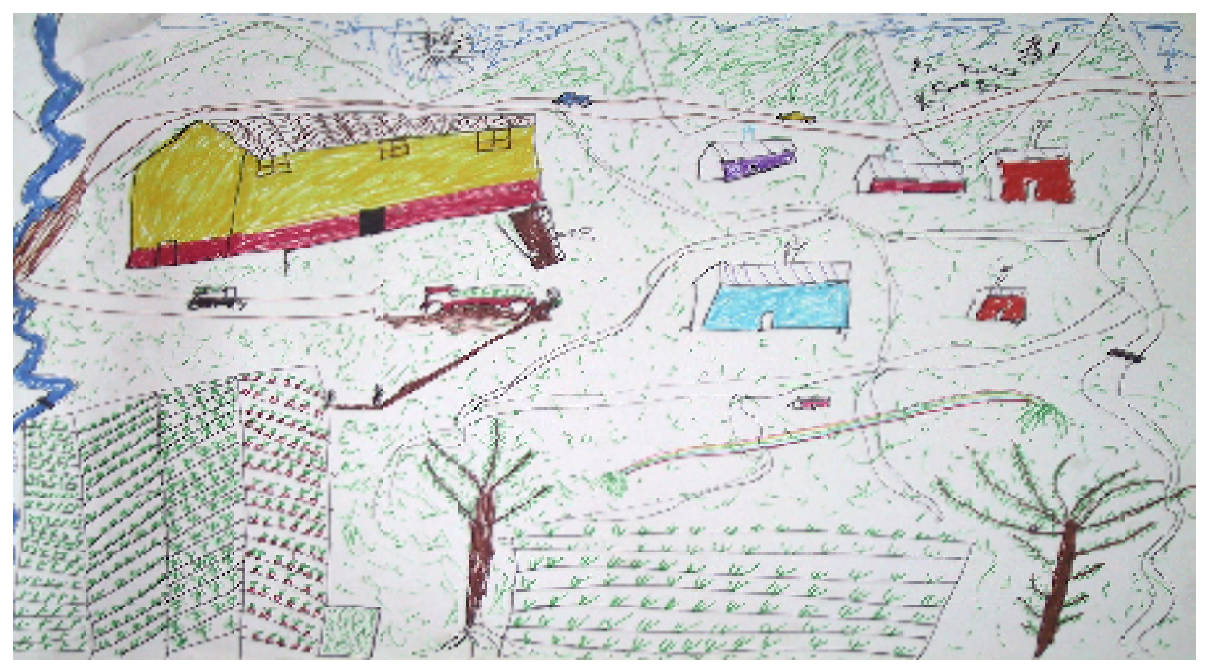

Figur 1: En tegning fra Cunya 
Denne tegning er lavet af en 13-årig pige fra Cunya. Et uddrag af pigens kommentarer til tegningen lyder:

Der er et stort hus, hvor folk ser fjernsyn. Man kan se, at der kommer røg ud af de andre huse. Der er en vej med biler; vejen går fra Huanta til Cunya. En lastbil med kål skal til Huanta, fordi der er et marked dér. En mand læsser lastbilen, og andre mennesker bærer kål fra markerne hen til lastbilen. Der er marker med hvidløg, kål, salat og radiser. Grøntsagerne er til at spise og til at sælge. Der er vandhaner til drikkevand, mange stier og en flod med en bro. I bjergene er der græs til dyrene, og man kan se, at jeg holder øje med dyrene sammen med min søster.

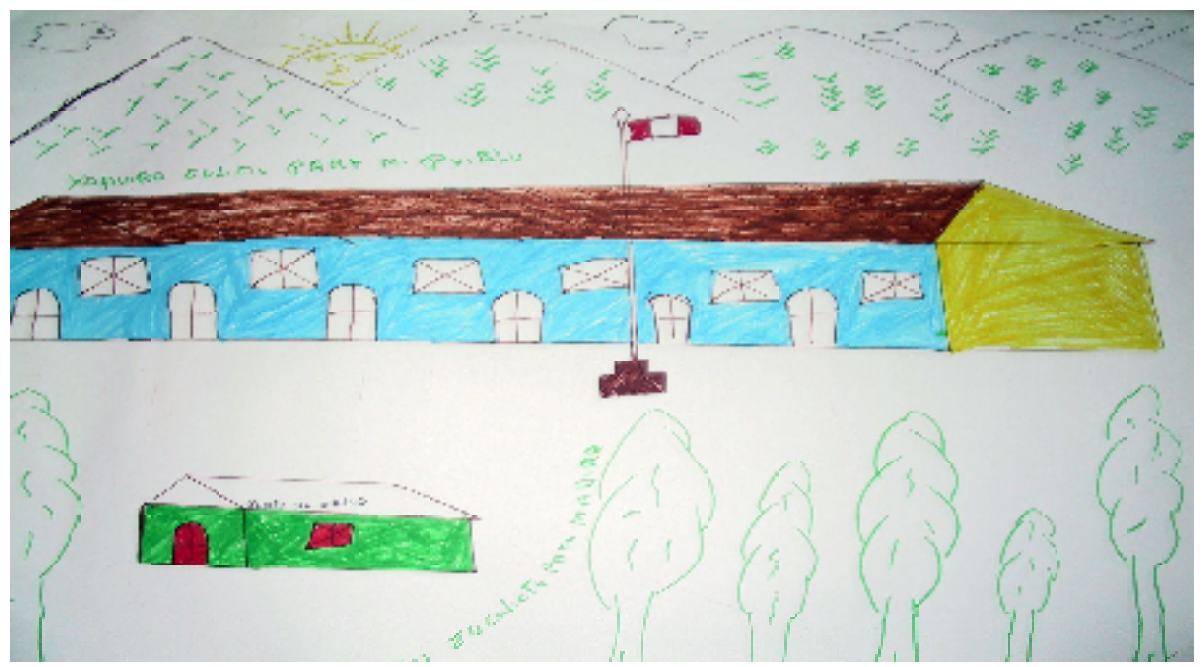

Figur 2: En tegning fra Ccarhuahurán

Denne tegning er udført af en 13-årig dreng fra Ccarhuahurán. Drengen forklarede følgende om sin tegning:

Tegningen viser en stor skole [til de højere klassetrin], fordi en stor skole vil forbedre landsbyen. Der er også en sundhedsstation, som er større og som har mere medicin [end den nuværende]. Dette vil sikre, at folk ikke dør. Der er mange træer, som skal bruges til at bygge skolen med. Man kan se Perus flag, fordi vi hilser det. Bjergene er grønne, fordi det er smukt, og solen giver varme - det er meget koldt i Ccarhuahurán. 
I analyseprocessen blev tegningerne kodet og en række kategorier udviklet. Denne proces indeholdt både et kvantitativ og et kvalitativt element. Der blev således foretaget en optælling af de forskellige elementer, som fandtes på tegningerne, men også børnenes kommentarer og fortællinger om tegningerne indgik i analysen (Lauritsen \& Mathiasen 2003). De udviklede kategorier er listet i tabel 1 .

Tabel 1: Kategorier

\begin{tabular}{ll}
\hline $\begin{array}{l}\text { Eksempler på elementer } \\
\text { tegnet af børnene }\end{array}$ & $\begin{array}{l}\text { Elementerne samlet i } \\
\text { forskerkategorier }\end{array}$ \\
\hline Landbrug, husdyr, foder til & Produktion. \\
dyrene. & Produktion af fødevarer til eget \\
& forbrug eller aktiviteter rettet mod \\
& salg. \\
\hline Leg, fælleshus. & Social aktivitet. \\
& Aktiviteter udført sammen med \\
& andre hovedsageligt som led i \\
& underholdning. \\
& Velfærdsinstitutioner. \\
& Institutioner som sørger for \\
& uddannelse og sundhed. \\
\hline Sundhedsstation, skole. & Hjemmeliv. \\
& Ting og aktiviteter relateret til \\
& personernes hjem. \\
\hline Huse, madlavning, familie. & Infrastruktur og kommunikation. \\
& Ting og aktiviteter relateret til \\
& kommunikation eller bevægelse \\
& inden for såvel som uden for \\
& landsbyen. \\
\hline Stier, veje, biler. & Symbolske praksisser. \\
& Ting og aktiviteter som værdsættes, \\
& \\
& \\
& \\
&
\end{tabular}


Udover de beskrevne kategorier viste det sig nødvendigt at udvikle yderligere to, som karakteriserer den måde, hvorpå børnene har tegnet og beskrevet forbindelser mellem elementer internt i landsbyen (integration) og mellem landsbyen og omverdenen (interaktion).

\section{Tabel 2: Relationer}

\begin{tabular}{ll}
\hline $\begin{array}{l}\text { Eksempler på relationelle } \\
\text { elementer tegnet af børnene }\end{array}$ & $\begin{array}{l}\text { Relationelle elementer samlet i } \\
\text { forskerkategorier }\end{array}$ \\
\hline Stier som forbinder bestemte & Integration. \\
områder i landsbyen. & Relationer mellem kategorier \\
& internt i landsbyen. \\
\hline Veje, biler, gæster. & Interaktion. \\
& Eksterne relationer som \\
& overskrider landsbyens \\
& geografiske grænse. \\
\hline
\end{tabular}

Ved hjælp af de ovenstående kategorier er det muligt at karakterisere, hvordan børnene forestiller sig, at deres landsby kunne blive i fremtiden. Som det vil fremgå, er der væsentlige forskelle mellem de to landsbyer.

\section{Cunya}

Kategorier: I Cunya er "produktion" dominerende, selvom andre kategorier også er væsentlige. At produktion er vigtig, viser sig ved, at der lægges stor vægt på landbruget. Der skal dyrkes foder til dyrene, og der er en stor variation af grøntsager, som skal sælges på markedet. Der er vandingskanaler og $\mathrm{i}$ det hele taget opmærksomhed overfor, at afgrøderne skal have vand. Fokuseringen på produktion kan ikke genfindes i tegningerne fra Ccarhuahurán.

Hjemmelivet er også tydeligt i Cunya-tegningerne; stort set alle har tegnet deres fremtidige hjem. Det er kendetegnende, at disse er bedre end de eksisterende, f.eks. har de "rigtige" døre og vinduer og ofte også tegltag. Selvom der er mange private hjem på tegningerne, er der også et stort antal sociale aktiviteter herunder faciliteter til leg og et fælleshus, hvor man kan se fjernsyn.

Endelig er det centralt, at børnene tegner velfærdsinstitutioner som skoler og sundhedsstationer.

Integration: Det er tydeligt, at Cunya tegnes som en landsby med et højt integrationsniveau. Alle tegningerne indeholder flere elementer og kategorier. Selvom produktion er vigtig, er der ingen tegninger, som kun relaterer sig til denne kategori. Endvidere er der gjort meget ud af stier og veje, som binder 
landsbyens forskellige aktiviteter og dele sammen. Man kan også se det høje integrationsniveau i forhold til kønnene: Tegningerne kan ikke umiddelbart "sorteres" i pige- og drengetegninger. Begge køn tegner f.eks. landbrugsproduktion og fremhæver, at produkterne skal kunne sælges.

Interaktion: Interaktionen mellem Cunya og den omgivende verden tegnes som en "to-vejsrelation". Landbrugsvarerne skal sælges andre steder, og børnene vil gerne rejse til andre byer. Samtidig lægger børnene vægt på, at der kommer besøgende til Cunya.

\section{Ccarhuahurán}

Kategorier: Sammenlignet med Cunya er det langt sværere at finde en dominerende kategori i Ccarhuahurán. Dette har først og fremmest at gøre med en skarp adskillelse mellem kønnene. Kategorierne "hjemmeliv" og "symbolske praksisser" finder man stort set udelukkende i pigetegningerne. Pigerne ønsker sig et flot hjem, ligesom de tegner blomster, som de kan sætte i hatten. Også det peruanske flag er tydeligvis interessant for pigerne, og de beskriver, at det er vigtigt, at man holder parader og hilser på flaget. Hverken blomster, som er knyttet til lokale skikke, eller flag er at finde i tegningerne fra Cunya.

For drengene i Ccarhuahurán er hjemmet og symbolske praksisser uinteressante. De tegner i stedet velfærdsinstitutioner, som oftest er gode, solide og flotte bygninger. F.eks. tegnede en dreng en stor sundhedsstation, "for en stor sundhedsstation sikrer, at flere folk kan kureres".

Integration: Tegningerne fra Ccarhuahurán afslører et billede af en landsby med et lavt integrationsniveau. Stierne sammenbinder ikke mennesker og aktiviteter i landsbyen, og som nævnt kan man også se en skarp adskillelse af offentlige og private rum, der er nært relateret til en adskillelse mellem kønnene. Drengene tager sig af det offentlige, pigerne af det private.

Interaktion: I modsætning til Cunya, hvor der blev lagt vægt på to-vejs relationer til omverdenen, er Ccarhuahuráns relationer "envejs-modtagende". Tegningerne viser således et billede af en landsby, som synes introvert og isoleret. I det omfang der findes veje og stier på tegningerne, er der ingen, der bruger disse til at komme væk fra landsbyen. De biler, der tegnes, ankommer til Ccarhuahurán; det er ikke et sted, man forlader. Dette understreges af, at landsbyens beboere i flere tilfælde tegnes som værende lukket inde bag hegn eller stenmure. Dette aspekt findes ikke i tegningerne fra Cunya.

\section{Sammenligning}

Som det fremgår, er tegningerne meget forskellige alt afhængig af, om de er tegnet af børn fra Cunya eller fra Ccarhuahurán. Tabel 3 opsummerer de væsentligste forskelle. 


\begin{tabular}{ll}
\hline Landsby & Dominerende kategorier og relationer \\
\hline Cunya & Produktion \\
& Højt integrationsniveau \\
& To-vejs interaktion \\
\hline Ccarhuahurán & Drenge: velfærdsinstitutioner \\
& Piger: hjemmeliv og symbolske praksisser \\
& Lavt integrationsniveau \\
& En-vejs, modtagende "interaktion" \\
\hline
\end{tabular}

Grounded Theory byder forskeren at udpege en "kernekategori" (Strauss \& Corbin 1990). Dette er vanskeligt i forhold til ovenstående, men det er dog muligt at indfange de væsentligste forskelle mellem landsbyerne i to "slagord". I forhold til tegningerne fra Cunya kan kommercialisering udpeges som en form for sammenfattende fortolkning. Produkterne produceres ikke alene for at kunne spises, men også for at kunne sælges. Og vejene og bilerne skal transportere varer til og fra markedet.

Det er umiddelbart vanskeligere at finde en enkelt dominerende fortolkning af tegningerne fra Ccarhuahurán, hvilket især skyldes forskellene mellem kønnene. Men for pigerne er det peruanske flag et væsentligt symbol, hvilket peger på en form for accept af den peruanske nationalstat. På samme måde er de institutioner, som drengene tegner, normalt leveret af nationalstaten, som, $i$ hvert fald til en vis grad, tager sig af sine borgeres sundhed og uddannelse. Man kan således pege på nationalisering som en kvalificeret karakteristik.

Det er relevant at overveje, hvorfor man kan iagttage disse forskelle mellem de to landsbyer. Svaret er langt fra enkelt, men en del af forklaringen kan findes i de to landsbyers forskellige "håndtering" af borgerkrigen. Beboerne i Ccarhuahurán blev tilbage i området, og med støtte fra hæren lykkedes det dem at afvise angreb fra "Den lysende sti". Netop hærens tilstedeværelse kan være en væsentlig årsag til, at "det nationale" fremhæves i Ccarhuahurán. For Cunyas vedkommende kan "kommercialiseringens" betydning ses på baggrund af landsbybeboernes flugt til byen under borgerkrigen, hvor de fik kendskab til andre livsformer, herunder markedets betydning. Ligeledes har en væsentlig del af de projekter, som udviklingsorganisationerne har gennemført i landsbyen, taget sigte på at uddanne beboerne til en varieret og bæredygtig landbrugsproduktion med henblik på køb af salg af varer på det nærliggende marked. 
Tilbage står imidlertid et spørgsmål om, hvilken betydning man kan tillægge det forhold, at børnene i Cunya havde erfaringer med fjernsyn, hvorimod børnene i Ccarhuahurán ikke havde adgang til denne teknologi. Spørgsmålet er ikke mindst interessant i forhold til antagelsen om, at IKT fører til en "formindskning" af verden og etableringen af forestillinger og fællesskaber, som ikke er bundet af lokale grænser. Dette er som nævnt en grundtese i Appadurais beskrivelse af "media-scapes", og man kunne i tilknytning hertil formode, at fjernsynet i Cunya leverer væsentlige ressourcer til børnenes konstruktion af forestillede verdener.

\section{Fjernsyn i Cunya}

I 1998 blev et fjernsyn med 32 kanaler installeret i Cunya. Fjernsynet står i landsbyens fælleshus, og indbyggerne placerer sig ofte stående (der er ingen stole) $i$ en halvcirkel omkring det. Beboerne skulle selv betale for fjernsynet, men resten af det tekniske udstyr (batterier, solceller, parabol) var en gave fra en amerikansk udviklingsorganisation som tak for godt samarbejde. Det er dog en peruansk udviklingsorganisation, IPAZ, som har koordineret de forskellige tiltag, og det er i vid udstrækning denne organisation, som har æren for, at projektet blev gennemført.

I en projektbeskrivelse begrunder IPAZ integrationen af fjernsynet på følgende måde:

Erfaringen med at fremme menneskerettigheder i områder med ekstrem fattigdom viser et dilemma mellem [på den ene side] at promovere borgerskab, demokrati og rettigheder og [på den anden side] understøtte processer, som tillader befolkningen at opnå goder og service, som traditionelt ikke er blevet leveret af staten eller andre institutioner.

Organisationens udfordring er, at den ikke kan isolere sine aktiviteter til menneskerettigheder, demokrati, ligestilling etc. Befolkningen ønsker visse materielle goder, og de forventer, at udviklingsorganisationerne også tager hånd om disse. Dette er væsentligt for en forståelse af, hvorfor fjernsynet blev installeret i Cunya. På et niveau er fjernsynet en teknologi, som befolkningen har et legitimt ønske om, men samtidig kan det bruges til at promovere nogle af de større punkter, som er på IPAZ' dagsorden. Håbet var, at fjernsynet kunne "forbinde Cunya til det regionale, nationale og globale kredsløb" og dermed skabe en følelse af at være "en del af verden". Mere konkret var det udviklingsorganisationens håb, at fjernsynet kunne bruges til at få viden, som er relevant i udviklingssammenhæng. Det drejer sig f.eks. om viden om priser på afgrøder og varer, viden om vejret, viden om kønsroller og i det hele taget viden, som gør det vanskeligere at "løbe om hjørner" med den ellers uuddannede befolkning i Cunya. 
Beboerne i Cunya ser fjernsyn mellem to og tre timer om dagen efter skolegang og arbejde. Fjernsynet er ofte indstillet på sydamerikanske "soaps" (telenovelas), men film ses også hyppigt, og mange af børnene har deres egen (amerikanske) favoritskuespiller. Endelig ser de voksne, og derfor også børnene, nyheder og vejrudsigter. En tilføjelse er, at børnene føler sig godt underholdt af reklamer, som de kan citere og "gennemspille".

Både børn og voksne får en mængde information om verden ved at se fjernsyn. De ved, at der er problemer med oversvømmelser i andre dele af Peru på grund af for meget regn. De ved også, hvem der er præsident og hvordan han ser ud. De ved, at der er 30 grader varmere i junglen end i Cunya. De ved, at Danmark muligvis er interesseret $i$ at importere asparges. Og de ved, at USA ligger langt væk og så videre. Fjernsynet er altså ikke uden effekt og alene det forhold, at fjernsynet er tilstede, udgør en forandring af dagliglivet i landsbyen. Men ser man på børnenes tegninger, får man et umiddelbart overraskende resultat: Ingen af børnene tegner noget, de har set i fjernsynet, og ingen nævner fjernsynet som inspirationskilde. I stedet peger børnene på andre inspirationskilder for deres forestillinger, ikke mindst ture til andre landsbyer og til Huanta, som er distriktets hovedby, og stedet hvor Cunya-familierne boede under borgerkrigen.

Den udviklingsorganisation, som installerede fjernsynet, håbede, at de derved kunne koble Cunya til regionale, nationale og globale kredsløb, men ovenstående sætter spørgsmålstegn ved, om dette er lykkedes. Fjernsynet er ikke uden indflydelse, men det spiller ikke nogen rolle for børnenes forestillinger om "et andet liv". Dette komplicerer antagelsen om, at en tilstedeværelse af ressourcer, leveret af "globale" flows, er en tilstrækkelig forudsætning for konstruktionen af (globale) forestillede fællesskaber. Andre og mere lokale faktorer er tilsyneladende afgørende.

\section{Diskussion}

I forlængelse af ovenstående rejser sig nogle væsentlige spørgsmål. Et er hvorfor børnene i henholdsvis Ccarhuahurán og Cunya forestiller sig deres fremtid på vidt forskellige måder. Undersøgelsen giver ikke et sikkert svar, men dog en begrundet formodning. Man kan således pege på børnenes egen mobilitet både under og efter borgerkrigen som afgørende. Børnene i Cunya har flere erfaringer fra ophold i de omkringliggende byer end børnene i Ccarhuahurán, hvilket tydeligt slår igennem i tegningerne. En anden forklaring er, at udviklingsorganisationerne har haft meget forskelligt aktivitetsniveau i de to landsbyer. I Cunya har disse organisationer initieret en synlig udvikling af landbrugsproduktionen og understreget vigtigheden af salg af landbrugsprodukter på det lokale marked i Huanta. I Ccarhuahurán derimod havde udviklingsorganisationerne endnu ikke taget fat, hvorimod staten har haft en større tilstedeværelse. Dette viser sig også tydeligt i tegningerne. 
Til gengæld er det påfaldende, at forskellen ikke kan henføres til tilstedeværelsen af fjernsyn i Cunya. Den ellers populære fjernsynskigning har ikke gennemslagskraft, når børnene forestiller sig, hvordan de gerne vil have deres fremtid ser ud. Interviews med den voksne del af befolkningen viser et lignende billede. Ligesom børnene henter også de voksne mange informationer fra fjernsynet, men dette viser sig ikke, når de tematiserer ønsker til den fremtidige udvikling.

En årsag til dette kan være, at de ting, der vises i fjernsynet, ligger for langt væk fra børnenes dagligdag. Fjernsynet viser en verden, som man kan få information om, men kun vanskeligt forbinde sig til. Dette underbygges af et interessant forhold ved tegningerne fra både Ccarhuahurán og Cunya. Det er således tankevækkende, at ingen af tegningerne er "vilde" og fantasifulde. Børnene ønsker sig ikke ret meget mere, end de har i forvejen. Tegningerne indeholder med andre ord kun få ting, som ikke i nogen grad findes i landsbyerne i forvejen. Dette kan skyldes, at områdets voldelige historie medfører en større grad af tilfredshed med det eksisterende; i forhold til krigen er den nuværende stabilitet en væsentlig forbedring. En anden mulighed er, at både den peruvianske stat og udviklingsorganisationerne har en interesse i, at udvikling "oversættes" med noget meget konkret og opnåeligt. Det er ikke hensigtsmæssigt, at folk bliver skuffede og vender sig mod udviklingsorganisationerne eller staten, som det skete under borgerkrigen. Udviklingsdiskursen disciplinerer folk til at ønske sig det opnåelige.

En sådan tolkning er blot én blandt flere mulige. Men pointen er, at der tilsyneladende er noget mere og andet på spil, som indebærer, at det ikke "automatisk" kan antages, at en kontakt til globale flow også har globaliserende effekter, og at IKT er adgangsbilletten til den globale landsby. Der er flere nuancer, og der er ikke nødvendigvis tale om, at man enten er koblet til eller koblet fra. Spørgsmålet er derfor nærmere, hvordan forbindelserne kan karakteriseres, og hvad det er, der gør nogle forbindelser mere relevante end andre. At besvare sådanne spørgsmål kræver påpasselighed over for anvendelsen af for store begreber, som gør grebet om globaliseringens indhold og implikationer for løst. I stedet er der behov for at supplere eksisterende forståelser og perspektiver med undersøgelser, som går tættere på globalisering som et mikro-sociologisk, empirisk fænomen.

\section{Noter}

Forfatterne ønsker at takke Peter Elsass og Casper Bruun Jensen for kommentarer til en tidligere version af denne artikel.

1. I denne artikel fokuseres på børnetegningerne, men i den samlede undersøgelse indgik også observation og kvalitative interviews med voksne. 


\section{Litteratur}

Anderson, Benedict 1991: Imagined Communities: Reflections on the Origin and Spread of Nationalism. London: Verso.

Appadurai, Arjun 1996: Modernity at Large: Cultural Dimensions of Globalization. Minneapolis: University of Minnesota Press.

Appadurai, Arjun 1999: "Disjuncture and Difference in the Global Cultural Economy", in Featherstone, Mike (ed.): Global Culture: Nationalism, Globalization and Modernity. London: Sage.

Barber, Benjamin 1995: Jihad vs. McWorld. New York: Random House.

Bauman, Zygmunt 1999: Globalisering: De menneskelige konsekvenser. København: Hans Reitzels Forlag.

Beck, Ulrich 2000: What is Globalization? Cambridge: Polity Press.

Castells, Manuel 1996: The Rise of the Network Society. Oxford: Blackwell.

Dybkjær, Lone \& Jørgen Lindegaard 2000. Digital Denmark - Conversion to the Network Society. Copenhagen: The Ministry of Research and Information Technology.

Glaser, Barney G. \& Anselm S. Strauss 1967. The Discovery of Grounded Theory: Strategies for Qualitative Research. New York: Aldine de Gruyter.

Harvey, David 1990: The Condition of Postmodernity: An Enquiry into the Origins of Cultural Change. Cambridge MA: Blackwell.

Hirst, Paul \& Grahame Thompson 2002: Globalization in Question. Cambridge: Polity.

Lauritsen, Peter \& Stinne H. Mathiasen 2003: “Drawing Development: Analysing Local Understandings of Development in Three Andean Communities". Development in Practice, 13, 1:27-39.

McLuhan, Marshall 1964: Understanding Media: The Extensions of Man. London: Routledge.

Ribeiro, Gustavo L. 1998: “Cybercultural Politics: Political Activism at a Distance in a Transnational World", in Alvarez, S. E.; E. Dagnino \& A. Escobar (eds.): Culture of Politics. Politics of Culture: Revisioning Latin American Social Movements. Boulder: Westview Press.

Stern, Steve (ed.) 1998: Shining and Other Paths: War and Society in Peru, 1980-1995. Durham: Duke University Press.

Strauss, Anselm \& Juliette Corbin 1990: Basics of Qualitative Research. Newbury Park: Sage.

Tsing, Anna 1999: "Notes on Culture and Natural Resource Management." Working Paper, Berkely Workshop on Environmental Politics, Institute of International Studies, University of California, Berkeley.

Tsing, Anna 2000: “The Global Situation". Cultural Anthropology, 15, 3:327-360.

Waters, Malcolm 2001: Globalization. London: Routledge. 